
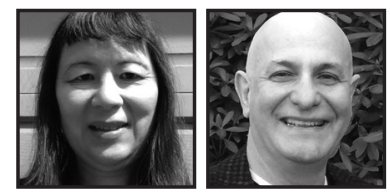

\title{
Suicide Is Painless: An Autoethnography of Tragedy
}

Karen V. Lee and Peter Gouzouasis, The University of British Columbia

\begin{abstract}
This autoethnographic duet is an artful inquiry about the tragedy of a beginning music teacher. A painful story about a music teacher and sexual allegations from an adolescent female, our composition blends music and story to transform understandings through creative engagement and push the boundaries to evoke visceral and emotional responses regarding suicide. Sociocultural issues draw deep reflection about wider political issues that arise for teachers who display difficulties with moral issues and misguided choices. The epiphany-epiphony (Gouzouasis, 2013) through story and music reveals the cultural irony of ideology and secrecy in professional misconduct. Unfortunately, in this circumstance, the outcome was catastrophic.
\end{abstract}

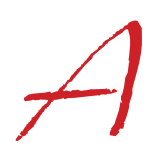

phone call changes my being. Words heard in a slow blur. I stare in space like a catatonic actor, ruined by the news. If I don't say his name, I won't feel anything. If I don't feel anything, I can be numb. I decide to visit my colleague, and share the life changing news.

"Hi, Peter."

As usual, he's playing the guitar in his office, yet another finger style arrangement of a jazz tune.

"What's up, Karen?" he responds, as he continues to finger pick the opening bars from the refrain of the Johnny Mandel tune, "Suicide Is Painless."

"Something happened to one of our past students. I need to share his story." 
"Okay, first listen to this." For a moment, Peter plays the Bill Evans version of the same song from his massive iTunes collection.1 He's using it to learn the lush, intricate, harmonic progressions and chord substitutions that Evans uses in his arrangement.

"You know the song, it's from Evan's last set of live recordings in 1980. He died 15 days later. In the mid-1980s, an old friend, jazz writer Gene Lees, called Bill's death 'the longest suicide ever.'"

Karen is visibly agitated, her brow laden with a sadness that he hasn't seen before.

"Sorry, Karen, tell me. Do I know him?" He turns the music way down, but it continues to softly play the refrain in the background.

"Yes, you do. I recall meeting him in 2004. He was 25 years old. It was a new term with new students. Always the same orientation and daily routine. Warmly, I greet each student with soothing music in the background. I monitor student moves by noticing those figuring out how to gain high marks from me. Students eager to learn: course content, tests, and instructor expectations. There are some faint, conspiratorial whispers out of range. For the next hour, I share my routine of breaking the ice like dim sum at a fancy Asian restaurant-tapas dishes of this, of that, with several doses of exotic food to entice student interests. Students engage in an icebreaker game. Their mouths move while they write on the page. Each student must gather three facts about other students, then share one fact with the cohort and explain why they're in the teaching degree program."

"Sure, I know your routines, Karen. What happened?"

Usually it's Peter who's telling long-winded stories about music and life, but this time he senses Karen's heavy heart and the need to listen to her pour out her emotions.

"I remember when he first entered the music room, salt and pepper hair with a sporty jeans and T-shirt. He carried himself with a boyish charm. He sat and smiled and spoke in hushed tones. His listeners laughed and giggled. Snippets of conversations between students came into range, but l'd already sensed the dynamics and attitudes. No blinders. He blipped my radar by typical, Dreikurs, attention-seeking behaviour. A few wisecracks and smart remarks, but it was obvious he was cocky. As teacher, you know the kind, Peter. He talks to a young blonde female who wears shorts. Quickly, he moves and mingles with a much heavier blonde, who laughs. Probably another wisecrack. He shakes her hand and moves again." 
For a brief moment I wondered, 'What are the odds he'll chat up another female?' But I knew the answer in advance. Surely, my daughter would call him a player. Suddenly, it was time to end the activity. As I gave the hand signal, he quickly gestures he'll return to the first blonde in shorts.

"Thanks, everyone. Now, for our sharing session," I announced.

An exception to every rule extends to new pre-service students because they can be silly. Facts start to pour out and there's laughter. I laughed. They laughed. Icebreakers involve folly and humor. It's the jitter and jest of meeting new people. We get in a groove and everyone shares information about others and themselves. Next. And next. And finally, it's his turn.

"Who is this character, Karen? You're keeping me on edge."

Karen ignores Peter's plea and pushes the story forward.

"I'm in this program to cruise for chicks," he bows and everyone giggles, "and to meet a trophy wife."

A strange character, he always made smart remarks with caustic quips. He is what he is with his cool, maverick attitude. I call on him for answers in class, but he reveals minimal depth in thinking. He asks the same questions that have already been answered. Is he distracted?

As class moved forward, so far, so good, as I decided to invite him to be a research participant for my doctoral inquiry on musicians-becoming-teachers.

"Sure, I have lots to tell you," he responded.

"I think I know who this person is," Peter says with a quizzical expression. Karen continues her story, moving in and out of tenses as if she's reliving the experiences she had with this "smooth operator."

Many voice messages went unanswered, and he was indecisive about a date and time for the interview. Finally, I arrived at his apartment building and noticed several rugged and scruffy people. A fearsome looking street thug smoking a cigarette eyes my parking skills. I'd not anticipated this area requiring extra precautionary measures. So, I put the security bar on the steering wheel of my Honda Civic. He lived on the first floor of an unkempt low-rise apartment building in Mount Pleasant. 
I buzz his suite number and he responds from his balcony. As I enter his apartment, it's obvious he doesn't value cleanliness. With three dirty cats, pet smell, cat pee on the carpet, and more filth, I sneeze and sneeze. Cruddy dishes litter the counters with piles in the sink. His clothes are hung on doorknobs and chairs. I sense his unease.

"Sorry, I just woke up. Have a seat."

"Where? I need to plug in my tape recorder."

"Okay, I'Il find an outlet somewhere."

During the interview, he answers coyly. Our chat confirms his stunted development-he's very young, very immature, and that's confirmed by a hint of arrogance. He tells me he doesn't have many music gigs, even though he deserves them due to his high musicianship skills. He wasn't in the local musicians' union. A few bucks here and there from odd gigs. After some interviewing, he shifts my attention to several bargains in his apartment.

"For extra cash, he sells amplifiers, mikes, guitars, some synths, and turntables galore. When he says 'Aye aye and good buy,' I laugh and see his humour draws to his apartment being an offshoot of 'The Captain's,' a rotund reseller of used, pawn shop merchandise who has poorly produced, incoherent commercials on latenight television. It's not merely an apartment but a musical emporium, as he sells cut-rate wares."

"I know who this person is now, but I forget his name. He seemed to be a time waster - talked a good gig but never wanted to sit down and pull some strings with me. It seemed like he had something to say, but an attention deficit buzz always had him moving from one topic to another, never wanting to talk about music teaching and learning," Peter interjects, "and he always wanted to sell me broken amplifiers he'd found on Craig's List."

Karen pushes on with her story. She has to get it all out.

"Yeah, I know, but a question of provenance flitted through my mind. Except for disease and pandemic in his apartment, this was a musician's dream. I recall seeing the acoustic guitar that some would call a treasure. A low price here, a discount there, I know I could buy an item for cheap. It was the Captain's scruffy first mate. Clearly, he had a secret preoccupation as pawnshop owner." 
"Someday, I hoped he'd have a better life. Someday, I hoped a life in teaching would resolve his financial issues. I thanked him and said I'd call to clarify the interview. He urged me to make a deal and buy something ... anything. Clearly, his enthusiasm was reserved for chicks and selling instruments, and not for school.

I left, inevitably, concluding that the interview was thin. I was so done. I needed to physically remove myself from the fetid chaos to detoxify from the sensory overload. Too much dirt and clutter in his apartment. It was about the worst environment possible for studying. I considered calling a biohazard crew. And even more distressingly, there was so little depth to his interview responses. That is, except for his real storyhe couldn't hide from his identity as a filthy hoarder."

I think about him, his words, and what I want to learn from him. I think about these things as I eat, walk, work, read, shower, and answer the phone. My last thought before I sleep, my first thought when I awake, "Aye aye, Good buy."

"That guy was some character. What happened, Karen?"

"It's like a horrible dream. My mind fails to process what I was told. This kind of news is the worst kind of news. But it's no mistake." I stare. Stare, because I don't know where I'm going or what I'm doing. It seems like I was hallucinating. I'm in a horrible neighbourhood inhabited by horrible people-drug dealers and addicts, criminals, and ex-cons. There are drugs and booze in paper bags, pipes, and hard-looking people.

Today, my life is hidden beneath a cold, frozen shell. The air is black and leaves are thick. I can't see anything from nights with streams of tears. The sickness drags me into bed. Knocks me out of life. I get into the shower and turn up the heat to wash sickness and guilt and shame from my body. Watch it gather at the drain and crush it with my feet. Make it disappear.

There are remnants of bile in my mouth. A small incision in my cheek from a bite brings a taste of blood.

“Some think I'm a strong person, but I'm not when students don't do well. I recall his youthful glow when talking about 'good buys.' His pride at phoning me to say he accepted a teaching position. A few months later, he was exuberant about getting married to a beautiful elementary school teacher. I try to forget his face but can't. What had really happened?"

"You tell me, Karen, what really happened?" 
“It's like a home movie on an endless loop. I can't stop hearing him say, 'I'm in this program to cruise for chicks.' But there must have been more to his story. Much more. I've always felt that teachers enter the profession not only to advocate their subject matter, but also the matter of life. We can be models of normalcy, of love, of trust, of happiness, of future, of friendship, of self, of sanity, of dignity, of humanity. But his life took a turn and reduces me to a lump of grief and heartache; his teaching ambitions were a smokescreen. I admit there were red flags and I never called him on it. It was all a lie. He knew what Groucho Marx meant by, 'If you can fake sincerity, the world is your oyster.' And so, Peter, there is much more to this story."

"After successfully teaching music at a local high school for a few years, a female high school student approaches the principal, accompanied by her parents. There are allegations of sexual harassment. Immediately, he was forced to take a leave of absence. Shocked faces meet shocked faces with voices becoming louder and more urgent."

I can only imagine what happened next. Half cocked, he returns home, a reminder that he is head over heels in debt. He parks in his garage and leaves the key in the ignition. Getting out of the car, he closes the garage door. He finds his music, Metallica's "Fade to Black" (Hetfield, Ulrich, Burton, \& Hammett, 1984):

$$
\begin{aligned}
& \text { Life, it seems, will fade away } \\
& \text { Drifting further every day } \\
& \text { Getting lost within myself } \\
& \text { Nothing matters, no one else. } \\
& \text { I have lost the will to live } \\
& \text { Simply nothing more to give } \\
& \text { There is nothing more for me } \\
& \text { Need the end to set me free. }
\end{aligned}
$$

No one but me can save myself, but it's too late Now I can't think, think why I should even try.

Yesterday seems as though it never existed Death greets me warm, now I will just say goodbye.

Throwing aside the many hoarded items in his garage, he finds a long hose. He connects the hose over the car exhaust pipe and turns the music louder. No cavalry in sight. No strength from his body. No wisecracks from his lips. Instead, I 
hear the arpeggioed acoustic guitar and screaming electric guitar accompaniment of "Fade to Black." There is light-headedness and confusion. Drunk and tipsy, he tries to get out of the car. But he's tired and spent. He gets back inside the car and closes the window. Slumping in the seat, he closes his eyes while his head leans back. As the music gets louder, there are dense clouds of fumes in the garage leaking into the car.

It takes all my strength to see, to inhale it all. To accept that toxic levels of carbon monoxide can asphyxiate. And it did.

\section{Exegesis}

The notion of sharing epiphanies is an early feature of autoethnography, and was particularly developed within this genre (Bochner \& Ellis 1992; Pelias, 2000; Banks \& Banks, 2000; Couser, 1997; Gouzouasis \& Lee, 2002; Sparkes, 2002). In other papers, Gouzouasis (2008a, 2008b) coined the term "epiphony" in reference to a realization that is evoked through sound, specifically, music. That is because the suffix, phony means sound (in Greek, $\varphi \omega v \eta$ ), and for musicians in particular, important discoveries about the self and others (e.g., music students, peers, colleagues) are often based upon acoustic experiences. And acoustic experiences require both sound production and listening, to the self and to others, to comprehend a situation or tale and relate it to personal and other experiences (Gouzouasis \& Leggo, 2016).

As an enlightened realization, an epiphany (in Greek, "epiphania") is often spurred by an object or event that enables the individual to make an inference or develop a new, deeper understanding of a phenomenon. Some may think of an epiphany as the result of a process. But the coincidence of Peter playing an arrangement of the song, "Suicide Is Painless" (Mandel \& Altman, 1970) was a harbinger of the story that Karen courageously unfolded that day in his office. We posit that music's powerful ways of eliciting thoughts, images, and feelings (without and with lyrics) was a visceral provocation to get the story out. Karen's process was embodied in reliving, and trying to make sense of, this tragic story of a young man who had a darkly colored, troubled past. Knowledge and wisdom are not the same, and we had neither; nor did we have the chance to speak with and offer help to our young teacher colleague. But someone could have offered hope-the hope that even though he may have committed a horrible mistake, he'd be able to reconstruct his life, someway and somehow, once the legal and personal issues had been settled. 
Pelias (2000) and Banks and Banks (2000) introduced the notion of the pedagogical nature of autoethnography - that autoethnography, in and of itself, may be interpreted as pedagogy (Banks \& Banks, 2000). The aim of autoethnography, especially in artistically written stories, is to convey meanings and not merely portray facts (Ellis, 2004). In a broader conceptualization, autoethnography enables us to examine the self and the other in relation to others in various settings. That is because a broader, nuanced understanding of the word auto reveals that autoethnographies are the joining of the self (i.e., the auto, from the Greek, autó), that (in Greek, that is also

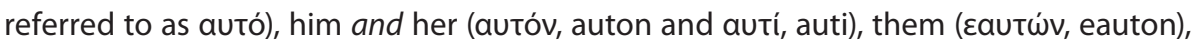
those (autá, auta), they (autoí, auti), culture (i.e., the ethno, $\varepsilon \theta v o$ ), and writing (i.e., the graphy, үрафń) (see Gouzouasis \& Ryu, 2015; Gouzouasis \& Regier, 2015). Thus, from a holistic and relational perspective, autoethnography is about and the ways we enact music, lyrics, poetry, and story as well as how we compose those artistic expressions. A multifaceted understanding of autó can bring us to new understandings of the self in relation to the world around us.

Our inquiry provides complex, multidimensional, artful pathways of understanding the arts-based researcher as artist/researcher/teacher (i.e., a/r/tographer). As we learn from the autoethnographic music and story telling-through the epiphany and epiphony-and the complex relationships between them, we learn to become more reflective, we learn to compose, we learn to listen to each other, we learn trust, we learn to lead a critical life (Pelias, 2000), we learn to become reflexive (Etherington 2004, 2007), and we learn new meanings of "that" (i.e., a secondary definition of autó in Greek) - that which it means to create anew and that which is meaningful to storytellermusicians - and all arts-based researchers who are firmly rooted in the arts and a commitment to lifelong art making. As we become more open to change, professional growth, listening, trust, and arts-based praxis, and we learn to better inquire through disciplinary and interdisciplinary frames of mind and co-create new arts-based forms, we become pedagogical (see Gouzouasis, Irwin, Gordon, \& Miles, 2013).

With that in mind, we know that university advisors and professors are not equipped to counsel our students, particularly when they are hiding a troubled past and present. The lyrics of the song referred to at the outset of our story tell us:

The game of life is hard to play

I'm gonna lose it anyway

The losing card I'll someday lay

So this is all I have to say. 
That suicide is painless

It brings on many changes

And I can take or leave it if I please.

I try to find a way to make

All our little joys relate

Without that ever-present hate

But now I know that it's too late, and ...

A brave man once requested me

To answer questions that are key

Is it to be or not to be

And I replied 'oh why ask me?'

It is astounding that a 14-year-old boy, the son of the director (Robert Altman) of

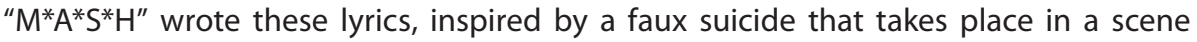
toward the end of the film. While somber and somewhat macabre, that movie scene had a happy ending. In real life, we are not equipped with answers, and neither are most professionals in the psychiatric field. If at all, we're fortunate to get a happy ending. While we, and health professionals, may hypothesize "why" people try to take their lives-and there are six "popular" reasons (Lickerman, 2012; i.e., the person is depressed, is psychotic, is impulsive, is crying out for help, has a philosophical desire to die, has made a mistake)—we never get to ask the person who has taken his or her life, "Why did you do it?" We can only hypothesize; we can only try to place ourselves in that person's shoes. Obviously, the accusation of sexual harassment was too much for the young man to bear as he saw that all that he'd collected-a house, a great job, a beautiful wife, his seemingly valuable belongings — vanish before his eyes in the flash of a brief, life-changing meeting with a school administrator.

We offer this story as provocation to help us be more aware of, and consider, that much more goes on in the lives of pre-service teachers than we may be aware. We know of many artists who have taken their lives over the centuries. We are aware of the ways that artists and arts teachers deeply feel and express themselves through their media. We call for the ABER community to think of ways that our artistic sensibilities and sensitivities can be used to find ways to help those who may be in trouble to help themselves, and to find ways that their artful souls can heal and reach out for support from like-minded peers-artist-researcher-teachers. 


\section{Note}

1. See the references (below) for the original recording information. The recording may also be found at: https://www.youtube.com/watch?v=hZDRk6HQ_ao

\section{References}

Banks, S.P., \& Banks, A. (2000). Reading "the critical life:" Autoethnography as pedagogy. Communication Education, 49(3), 233-238.

Bochner, A.P., \& Ellis, C. (1992). Personal narrative as a social approach to interpersonal communication. Communication Theory, 2(2), 165-172.

Couser, G.T. (1997). Recovering bodies: Illness, disability, and life writing. Madison, WI: University of Wisconsin Press.

Ellis, C. (2004). The ethnographic I: A methodological novel about autoethnography. Walnut Creek, CA: AltaMira Press.

Etherington, K. (2004). Becoming a reflexive researcher: Using our selves in research. London: Jessica Kingsley.

Etherington, K. (2007). Ethical research and reflexive relationships. Qualitative Inquiry, 13(5), 599-616.

Evans, B. (2000). Theme from $M^{*} A^{*} S^{*} H$ (Suicide is painless). Last Waltz: The final recordings live at Keystone Korner, September 1980. [CD]. Berkeley, CA: Milestone Records.

Gouzouasis, P. (2008a). Music research in an $a / r /$ tographic tonality. Journal of the Canadian Association for Curriculum Studies, 5(2), 33-58.

Gouzouasis, P. (2008b). Toccata on assessment, validity, and interpretation. In S. Springgay, R.L. Irwin, C. Leggo, \& P. Gouzouasis (Eds.), Being with a/r/t/ography (pp. 219-230). Rotterdam: Sense Publishers.
Gouzouasis, P. (2013). The metaphor of tonality in artography. The UNESCO Observatory E-Journal, 3(2). Retrieved from http://web. education.unimelb.edu.au/UNESCO/ejour$\mathrm{nal} /$ index.html

Gouzouasis, P., Irwin, R. L., Gordon, C., \& Miles, E. (2013). Becoming pedagogical through $a / r /$ tography in teacher education. International Journal of Education \& the Arts, 14(1). Retrieved from http://www.ijea.org/v14n1/ v14n1.pdf

Gouzouasis, P., \& Lee, K.V. (2002). Do you hear what I hear? Musicians composing the truth. Teacher Education Quarterly, 29(4), 125-141.

Gouzouasis, P., \& Leggo, C. (2016). Performative research in music and poetry: A pedagogy of listening. In P. Burnard, L. Mackinlay, \& K. Powell (Eds.), The Routledge International Handbook of Intercultural Arts Research (pp. 454-466). Oxfordshire, UK: Taylor \& Francis/Routledge.

Gouzouasis, P., \& Regier, C. (2015). Adolescent love and relationships: A songwriting teacher's autoethnography. Journal of Artistic \& Creative Education, 9(1), 68-98.

Gouzouasis, P., \& Ryu, JY. (2015). A pedagogical tale from the piano studio: Autoethnography in early childhood music education research. Music Education Research, 17(4), 397-420.

Hetfield, J., Ulrich, L., Burton, C., \& Hammett, K. (1984). Fade to black. On Ride the Lightning [record]. Megaforce, Elektra. 
Lickerman, A. (2012). The undefeated mind: On the science of constructing an indestructible self. Daytona Beach, FL: Health Communications.

Mandel, J., \& Altman, M. (1970). Suicide is painless. On $M^{*} A^{*} S^{*} H$ (Original Soundtrack Recording) [record]. Columbia/CBS. (1969)

Pelias, R. (2000). The critical life. Communication Education, 49(3), 220-228.
Sparkes, A. C. (2002). Autoethnography, self-indulgence or something more? In Arthur Bochner \& Carolyn Ellis (Eds.), Ethnographically speaking: Autoethnography, literature and aesthetics (pp. 209-232). New York: Alta Mira Press.

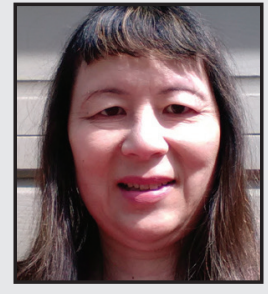

Karen V. Lee, Ph.D. is a Lecturer, Faculty Advisor and co-founder of Teaching Initiative for Music Educators cohort (TIME; 2000-present), at the Faculty of Education at The University of British Columbia. Her research interests include issues of music and music teacher education, performance ethnography, memoir, women's life histories, artography, writing practices, and autoethnographic inquiry to qualitative research. Her doctoral dissertation was a collection of short stories, Riffs of Change: Musicians Becoming Music Educators, the first ABER dissertation in Music Education (2004). Currently, she teaches university undergraduate and graduate students in music and general education, in traditional and online contexts.

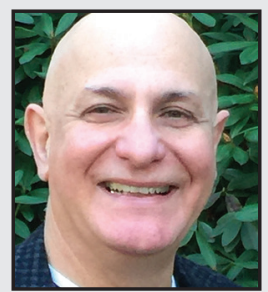

Peter Gouzouasis is a Professor and Deputy Head in the Department of Curriculum and Pedagogy at UBC. A member of the $A / r /$ tography Group at UBC, much of his work over the past 25 years has focused on Arts learning and teaching, creativity in teaching and learning, alternative forms of learning, socioemotional and motivational aspects of the Arts in learning, the role of the Arts in academic achievement, informal-unstructured learning in music and digitally infused classrooms, and the roles of digital technologies in Arts learning. Since 2000, his writing is focused in Arts Based Educational Research (ABER) and Creative Analytical Practices (CAP), in solo, duo, and ensemble composed publications. 